\section{Fas ligand is not only expressed in immune privileged human organs but is also coexpressed with Fas in various epithelial tissues}

\author{
Luc Xerri, Elisabeth Devilard, Jacques Hassoun, Claude Mawas, Françoise Birg
}

\begin{abstract}
Aims-To confirm the recent data obtained in mice, showing that the Fas ligand (FasL) is involved in the phenomenon of "immune privilege"(the apparent defect of the immune system in specific anatomical sites) and to extend this finding to humans.
\end{abstract}

Methods-The expression of FasL was analysed in a panel of histologically normal human tissues by reverse transcriptase polymerase chain reaction and Western blotting. The tissues sampled were brain, breast, bone marrow, oesophagus, kidney, liver, lung, lymph node, ovary, pancreas, pituitary gland, prostate, spleen, stomach (antrum and fundus), striated muscle, testis, thyroid, and uterus. These were obtained from patients with various neoplastic and nonneoplastic disorders; placental tissue was obtained after normal obstetric delivery, and spontaneous or voluntary abortion.

Results-Strong FasL expression was detected in testis and placenta. FasL expression was also detectable, although it was seen to a lesser extent, in oesophagus, prostate, lung, and uterus, which also coexpressed variable amounts of Fas mRNA or protein or both. The other organs tested for FasL expression were all negative.

Conclusions-FasL in humans is expressed predominantly in immune "sanctuaries" such as testis and placenta, suggesting that, similar to mice, this expression may contribute to the immune privileged status of these organs, by preventing dangerous inflammatory responses. The coexpression of FasL and Fas in particular epithelia suggests that the physiological cell turnover of some tissues may be regulated by the Fas-FasL apoptotic pathway.

(F Clin Pathol: Mol Pathol 1997;50:87-91)

Keywords: Fas/Fas ligand; Western blot; reverse transcriptase polymerase chain reaction; immune privilege

Correspondence to Dr Luc Xerri, Département de Pathologie, and INSERM U 119, Institut

Paoli-Calmettes, 232

Boulevard de Sainte

Marguerite, BP 156, 13273

Marseille, CEDEX 9,

France.

Accepted for publication 14 January 1997 growth factor receptor, CD27, CD30, CD40, OX40, and 4-1BB. ${ }^{4}$ Among these receptors, Fas and the p 55 TNFR share a 70 amino acid intracellular "death domain" that transduces signals for cell death. ${ }^{5}$ Fas mediates apoptosis when cross-linked with agonistic anti-Fas antibodies. ${ }^{67}$ FasL is a $40 \mathrm{kDa}$ type II membrane protein expressed as a membrane bound form that is proteolytically processed into a soluble cytokine retaining biological activity. ${ }^{8-11}$

There is increasing evidence from $l p r$ and gld mice models that CD95/CD95 ligand mediated apoptosis is a crucial regulatory process which limits immune response and provides a safeguard against emergence of autoreactive lymphocytes. ${ }^{12} 13 \mathrm{lpr}$ mutant mice harbour either an early transposable element or a mutation in the Fas gene, which either reduces severely the expression of a full size Fas transcript, or abolishes its ability to transduce an apoptotic signal. ${ }^{12}$ gld mice harbour a point mutation in the extracellular domain of FasL $^{14}{ }^{15}$; this mutation abolishes the binding between FasL and its receptor. Mice carrying a homozygous mutation for either $l p r$ or gld develop similar phenotypes, characterised by massive lymphadenopathy, splenomegaly, B cell activation, and hypergammaglobulinaemia. ${ }^{1213}$ Lymphadenopathy in $l p r$ and gld mice results from the expansion of a nonneoplastic subset of chronically activated cells that are $\mathrm{TCR}^{+}, \mathrm{CD}^{+}, \mathrm{CD}^{-}$, and $\mathrm{CD}^{-}$(doubly negative $\mathrm{T}$ cells). ${ }^{12}{ }^{13}$ The major immune defect in $l p r$ and gld mice appears to be the defective TCR induced death of mature $T$ cells, which results in a failure in peripheral, rather than thymic, $\mathrm{T}$ cell deletion. ${ }^{12}{ }^{13}$

The human counterpart of lpr mice is the recently described auto-immune lymphoproliferative syndrome, caused by dominant interfering Fas mutations. ${ }^{16}{ }^{17}$ Affected children have a defect in apoptosis of phenotypically normal mature $T$ cells, and present with acccumulation of doubly negative $T$ cells in spleen and lymph nodes. ${ }^{16} 17$

Because of its capacity to induce apoptosis of $T$ cells, FasL has been thought to be involved in the phenomenon of "immune privilege". ${ }^{18} \mathrm{Im}$ munologically privileged sites are regions of the body, such as the eye and brain, where the immune system does not appear to function. ${ }^{19}$ Testis also acts as a sanctuary in which infectious organisms, tumour cells, or allogeneic grafts neither elicit destructive nor protective immunity. ${ }^{20}$ The concept of immune privilege p55 and p75 TNFRs, the low affinity nerve
Fas/CD95 and its ligand (FasL) are members of two superfamilies of complementary receptors and ligands, respectively, that play important roles in immune regulation. ${ }^{1}$ Fas, also called APO $-1,{ }^{23}$ is a $45 \mathrm{kDa}$ type I membrane protein belonging to the tumour necrosis factor receptor (TNFR) superfamily that includes the 
can be extended to the observed lack of immune response of mothers against embryos during pregnancy, which remains an enigma. FasL was shown recently to be a key effector of immune privilege in the mouse; thus, it is expressed abundantly in testes and eyes, where it can induce the apoptosis of migrating immune and inflammatory cells. ${ }^{1821}$

In order to confirm and extend these data to humans, we analysed the expression of FasL in human tissues by combining reverse transcriptase polymerase chain reaction (RT-PCR) amplification and Western blot analysis.

\section{Methods}

TISSUE SAMPLING

Histologically normal specimens were surgically removed from various organs-brain, breast, bone marrow, oesophagus, kidney, liver, lung, lymph node, ovary, pancreas, pituitary gland, prostate, spleen, stomach (antrum and fundus), striated muscle, testis, thyroid, and uterus. Some of the patients presented with a benign tumour located in the same organ as the tissue sampled, but at a distance from the normal tissue sample (breast, lung, pituitary gland, prostate, thyroid). Other patients suffered from non-neoplastic diseases (kidney, lymph node, ovary, spleen, stomach, uterus). Bone marrow, liver, pancreas, and striated muscle were taken from patients with a malignant tumour in another organ. Only the brain and testis samples corresponded to histologically normal areas located at a distance from a malignant tumour in the same organ. The placental specimens were obtained after normal obstetric delivery, and spontaneous or voluntary abortion. RNA could be obtained from at least one sample of each normal tissue. The remaining tissues were processed for immunohistochemistry or Western blot analysis.

\section{CELLS AND ACTIVATION CONDITIONS}

The Jurkat $T$ cell line and human peripheral blood lymphocytes (PBL) from a healthy donor were used as positive controls for FasL mRNA expression. Jurkat cells were stimulated with phytohaemagglutinin (PHA, Sigma, Dorset, UK) $(10 \mu \mathrm{g} / \mathrm{ml})$ for one or two hours. PBL were activated with $2.5 \mu \mathrm{g} / \mathrm{ml}$ of PHA and $30 \mathrm{U} / \mathrm{ml}$ of recombinant human interleukin-2 (IL-2) (Proleukin, Chiron, France), then grown for four days in medium containing $20 \mathrm{ng} / \mathrm{ml} \mathrm{IL-2}$. Cells were restimulated with $1 \mathrm{ng} / \mathrm{ml}$ of phorbol myristic acetate (PMA, Sigma) and $500 \mathrm{ng} / \mathrm{ml}$ of concanavalin A (ConA, Sigma) for 24 hours as described previously $^{11}$ prior to $\operatorname{poly}(\mathrm{A})^{+}$RNA preparation. $^{22}$

RT-PCR ANALYSIS OF FASL AND FAS EXPRESSION Total RNAs were prepared from frozen tissues by lysis in guanidium isothiocyanate. ${ }^{22}$ Reverse transcription was performed as described previously, ${ }^{23}$ using $1 \mu \mathrm{g}$ of poly(A) ${ }^{+}$RNA from control cells, and $1 \mu \mathrm{g}$ of total RNA from tissues. One quarter of the cDNA preparation was used for FasL amplification using a 20-mer sense oligonucleotide (5'-CTACAGGAC TGAG AAGAAGT-3') upstream of the initia- tion codon, and a 22-mer antisense oligonucleotide (5'-CAACATTCTCGGTGCCTGTA AC-3') downstream of the termination codon. $^{10}$ Oligonucleotide primers for Fas (sense primer, 5'-GTAAAG TATAGTATTT GAGTGCAG-3' (nucleotide positions 17181744), and antisense primer, 5'-CATT TTCGGGGGTGG-3' (positions 21752191)) were in the non-coding region; they both amplify mature mRNAs. ${ }^{23}$ Integrity of RNA samples had been proved by means of electrophoresis of an aliquot on denaturing agarose/formaldehyde gel, and was further checked by performing control amplification for human $\beta$ actin (sense primer, 5'TACCACTGGCATCGT GATGGACT-3', and antisense primer 5'-TCCTTCTGCA TCCTGTCGGCAAT-3'). The cDNA was mixed with $50 \mu \mathrm{l}$ of a PCR mixture containing the reaction buffer and $2.5 \mathrm{U}$ of Taq polymerase (Perkin Elmer Cetus, New Jersey, USA). The PCR cycle profile was as follows: denaturation $\left(94^{\circ} \mathrm{C}\right.$ for one minute (two minutes for the first cycle) $)$, annealing $\left(55^{\circ} \mathrm{C}\right.$ for two minutes), and extension $\left(72^{\circ} \mathrm{C}\right.$ for three minutes (10 minutes for the last cycle)); 30 cycles of amplification were used. PCR products were visualised in ethidium bromide stained $1.5 \%$ agarose gels.

\section{SOUTHERN BLOT ANALYSIS}

PCR products separated by means of gel electrophoresis were transferred to Hybond $\mathrm{N}^{+}$ membranes (Amersham, Buckinghamshire, $\mathrm{UK})$ as recommended by the manufacturer. Membranes were prehybridised for two hours at $45^{\circ} \mathrm{C}$ in $5 \times \mathrm{SSC}$ containing $0.1 \%$ laurylsarcosin, $0.02 \%$ SDS and $0.5 \%$ blocking reagent (Boehringer Mannheim, France). They were hybridised overnight at $45^{\circ} \mathrm{C}$ in the same buffer containing a digoxigenin labelled internal oligonucleotide: an 18-mer (CAAAT AGGCCACCCCAGT, spanning the $3^{\prime}$ end of exon 2 and the $5^{\prime}$ end of exon 3 ) for FasL, and a 24-mer (5'-ACATGTCATGAACCCATG TTTGCA-3' (nucleotide positions 21182142)) for Fas, respectively. Oligonucleotide probes were labelled with a 3' tailing kit (Boehringer Mannheim) according to the supplier's recommendations. After hybridisation, filters were washed twice for 10 minutes at room temperature in $2 \times$ SSC containing $0.1 \%$ SDS and twice for 10 minutes at $55^{\circ} \mathrm{C}$ in $0.1 \times \mathrm{SSC}$ containing $0.1 \%$ SDS, then visualised using a chemiluminescence detection kit (Boehringer Mannheim).

WESTERN BLOT ANALYSIS

Frozen tissues, crushed in liquid nitrogen, were thrown in lysis buffer ( $1 \%$ SDS, $1 \mathrm{mM}$ sodium vanadate, $10 \mathrm{mM}$ Tris $\mathrm{HCl}, \mathrm{pH} 7.4)$ and heated in a microwave oven for $10-15$ seconds. Proteins from lysates were separated by $7.5 \%$ SDSPAGE and transferred to Immobilon-P membranes (Millipore, Massachusettes, USA) as recommended by the manufacturer. Detection of FasL was performed with a mouse IgG3 monoclonal antibody (MoAb) (Transduction Laboratories, Kentucky, USA), raised against an $18 \mathrm{kDa}$ polypeptide corresponding to amino 


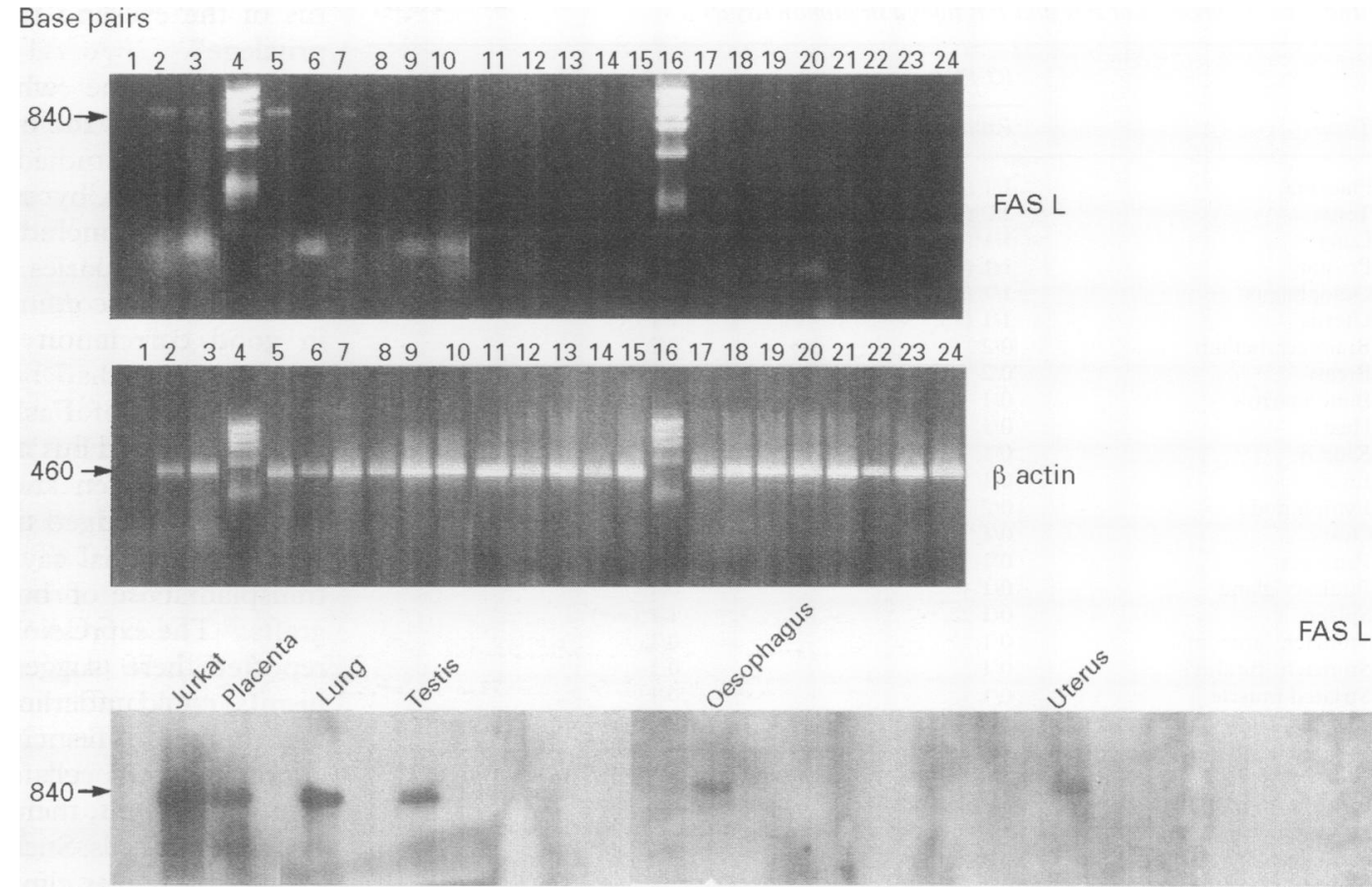

Figure 1 Expression of the Fas ligand in human tissues. Upper panel: RT-PCR detection of FasL transcripts in normal human tissues: (1) negative control, (2) positive control (PHA activated furkat cells), (3) placenta, (4 and 16) DNA molecular weight markers, (5) lung, (6) heart, (7) testis, (8) liver, (9) breast (sample a), (10) kidney, (11) oesophagus, (12) stomach (antrum), (13) striated muscle, (14) thyroid gland, (15) breast (sample b), (17) ovary, (18) spleen, (19) uterus, (20) cerebellum, (21) pituitary gland, (22) brain (frontal lobe), (23) total bone marrow, (24) lymph node. The amplified FasL product is an 840 base pair band (arrow), detected in the positive control (lane 2) and in placenta (lane 3), lung (lane 5), and testis (lane 7). Middle panel: Ethidium bromide stained agarose gel containing aliquots of cDNA amplified with the $\beta$ actin primers and arranged in the same order as the upper panel. The $\beta$ actin PCR product is a 460 base pair band. Lower panel: Same as upper panel after Southern blotting and hybridisation with a FasL specific digoxigenin-labelled probe, which revealed a weak positivity in oesophagus (lane 11) and uterus (lane 19). Other tissues were negative.

acids 116-277 of human FasL. Immunoreactive material was visualised by enhanced chemiluminescence (Amersham). Stimulated Jurkat cells served as positive controls. Negative controls were an ovalbumin/bovine serum albumin solution and unstimulated Jurkat cells. To confirm the specificity of the PCR data, a representative panel of negative and positive samples from neoplastic and normal tissues were analysed.

\section{IMMUNOHISTOCHEMISTRY}

Immunodetection of Fas was performed in frozen sections as described previously ${ }^{24}$ using the $\mathrm{MoAb} \mathrm{CH}-11$ (Immunotech, Marseille, France). Reactive lymph nodes were used as positive controls.

\section{Results}

FASL AND FAS MRNA EXPRESSION

The results of the RT-PCR experiments are illustrated in figure 1 , and summarised in table 1. PCR analysis was repeated at least twice for each sample. The relative differences in amplification levels were observed reproducibly in the various experiments, indicating that they reflect differences in mRNA concentrations, rather than random variations. The relative levels of FasL RNA expression could thus be estimated after normalisation with a control RT-PCR for actin.

A strong FasL expression was observed in placenta and testis samples, and moderate positivity was observed in lung and prostate samples using ethidium bromide staining of the gels. The faint bands observed in specimens of oesophagus and uterus were clearly detectable on Southern blot hybridisation. All other tissues analysed for FasL mRNA expression were negative. Fas expression assayed by RT-PCR was also negative in the same samples; namely, placenta, testis, heart, pituitary gland, stomach, striated muscle, thyroid, and brain; whereas liver, lung, kidney, ovary, prostate, oesophagus, uterus, breast, lymph node, pancreas, and spleen were positive.

FASL AND FAS PROTEIN EXPRESSION

Western blot analysis of FasL expression correlated with the PCR data. The expected $37 \mathrm{kDa}$ band was detected in the placenta, whereas PCR negative samples such as lymph node were negative (figure 2). The Fas protein was detected by immunohistochemistry in lung, prostate, and ovary, whereas three placenta samples were negative (data not shown).

\section{Discussion}

The Fas-FasL apoptotic pathway has been shown to play a key role in the immune system by triggering the activation induced suicide of $\mathrm{T}$ cells. ${ }^{25}$ Resting $\mathrm{T}$ cells normally express low amounts of Fas; this expression increases significantly within hours of engagement of their antigen receptor. ${ }^{26}$ Several days after the initial activation, this pathway becomes effective, and $T$ cells undergo apoptosis via cross-linking of the FasL concomitantly upregulated in activated $\mathrm{T}$ cells. ${ }^{27} \mathrm{Fas}$ is also expressed in non-lymphoid tissues ${ }^{28}$ as diverse as liver, heart, ovary, and lung, where its physio-

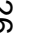
స్ట

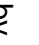
$\stackrel{乛}{\mathbb{C}}$ $\stackrel{\mathscr{\infty}}{\longrightarrow}$ 
Table 1 Expression of Fas and Fas ligand in human tissues

\begin{tabular}{lll}
\hline & $R T-P C R$ positivity & \\
\cline { 2 - 3 } Tissue & Fas ligand & Fas \\
\hline Placenta & $1 / 1(+++)$ & $0 / 1$ \\
Testis & $2 / 2(+++)$ & $0 / 2$ \\
Lung & $1 / 1(++)$ & $1 / 1(+)$ \\
Prostate & $1 / 1(++)$ & $1 / 1(+)$ \\
Oesophagus & $1 / 1(+)$ & $1 / 1(+/-)$ \\
Uterus & $1 / 1(+)$ & $1 / 1(+)$ \\
Brain/cerebellum & $0 / 2$ & $0 / 2$ \\
Breast & $0 / 2$ & $2 / 2(+/-)$ \\
Bone marrow & $0 / 1$ & $N D$ \\
Heart & $0 / 1$ & $0 / 1$ \\
Kidney & $0 / 1$ & $1 / 1(+/-)$ \\
Liver & $0 / 1$ & $1 / 1(++)$ \\
Lymph node & $0 / 2$ & $2 / 2(+)$ \\
Ovary & $0 / 1$ & $1 / 1(+/-)$ \\
Pancreas & $0 / 1$ & $1 / 1(+/-)$ \\
Pituitary gland & $0 / 1$ & $0 / 1$ \\
Spleen & $0 / 1$ & $1 / 1(++)$ \\
Stomach (antrum) & $0 / 1$ & $0 / 1$ \\
Stomach (fundus) & $0 / 1$ & $0 / 1$ \\
Striated muscle & $0 / 1$ & $0 / 1$ \\
Thyroid & $0 / 1$ & $0 / 1$ \\
t & &
\end{tabular}

^Number of positive samples /number of independent samples analysed. The intensity of PCR bands is given in parentheses: +++ , strong band on ethidium bromide stained gel, ++ , weak band on ethidium bromide stained gel; + , band detected after Southern blot hybridisation; +1-, weak band detected after Southern blot hybridisation.

ND, not done for technical reasons.

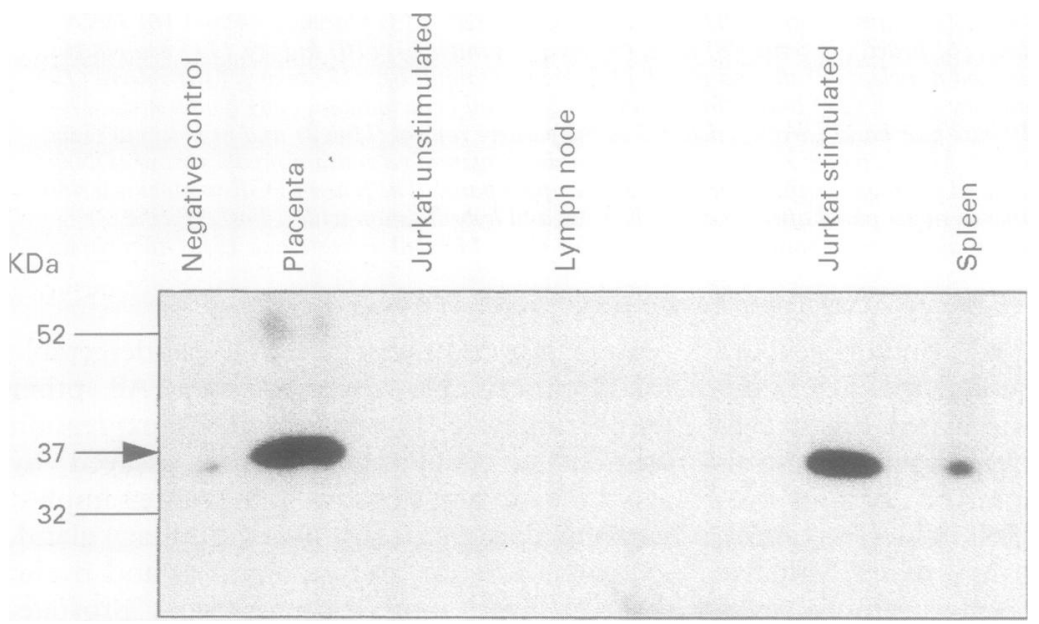

Figure 2 Western blot analysis of Fas ligand expression in a panel of normal tissues. The $37 \mathrm{KDa}$ FasL protein was detected in PCR positive samples such as placenta and stimulated furkat cells. A faint signal was also detected in a PCR negative spleen sample, which may reflect a low level of FasL protein expression, more easily detectable than the corresponding transcript. tus of the eye and testis known as "immune privilege".

To determine whether FasL expression could represent the basis of immune privilege in humans, we studied FasL mRNA expression and localisation by using RT-PCR to analyse various organs, including those known to act as immune sanctuaries. We found that FasL expression was confined to a few specific sites, in good correlation with earlier findings in mice.

Expression of FasL mRNA has been reported in rodent but not in human testis. ${ }^{18}$ Testis has long been known to be a remarkably immune priviledged site; rat testis, when placed in the abdominal cavity, allows the successful transplantation of both allografts and xenografts. ${ }^{20}$ The expression of FasL in human testis reported here suggests that similar mechanism(s) could underlie immune privilege in mice and humans. Testicular FasL might induce apoptosis of $T$ cells activated in response to tumour antigens, thereby favouring the growth of neoplastic cells. Such a hypothesis may help to explain particular clinical observations, like the agressive behaviour of primary testicular lymphomas which frequently relapse in the controlateral testis. ${ }^{34}$ It may be that one of the purposes of immune privilege in the testis could be to arrest the spread of dangerous inflammatory responses, potentially able to destroy germinal cells and thus threaten the fate of the species.

The demonstration of FasL expression in the placenta is of special interest, as the mechanisms preventing rejection of the embryo by the maternal immune system are subject to speculation. Preliminary immunohistochemical analysis of FasL expression seemed to localise the staining in the fetal trophoblast covering the placental villi (Xerri, unpublished observation). The trophoblast is situated at a strategic interface between maternal and fetal circulations; the apoptotic signals produced by trophoblastic FasL could regulate the immune traffic and maintain maternal tolerance by preventing the activated lymphocytes from entering the fetal cellular compartment. Another possibility may be that FasL regulates the growth of placenta itself via an autocrineparacrine loop involving the Fas-FasL apoptotic pathway. This possibility, however, appears unlikely as Fas expression was not detected in the FasL positive placenta specimen. This negative result does not exclude a transient upregulation of Fas during critical stages of placental maturation.

It has long been thought that immune privilege in specific human organs was passively maintained by particular anatomic barriers which prevent inflammatory cells or antigens from entering the privileged sites. ${ }^{35}$ Although this hypothesis appears unlikely regarding tissues expressing FasL, it seems relevant for the blood-brain barrier, because our results showed a lack of FasL expression in the brain, as previously demonstrated in mice brain. ${ }^{33}$

Finally, while it is obvious that some important parts of the body must be protected from immune reactions, it is less easy to explain why we observed FasL expression in tissues capable and eye, and very low levels in small intestine and uterus. ${ }^{833}$ These results suggest that the physiological role of FasL extends beyond that exerted on the immune response, and that it may be the basis of the particular immune sta- 
of regeneration, such as oesophagus, lung, prostate, and non-pregnant uterus. It could be that the proximity of a malignant tumour might influence the expression of FasL in the surrounding normal tissue, but this is unlikely because most of our FasL positive samples came from patients presenting with a nonneoplastic disease or a benign tumour. The co-expression of Fas in most of these tissues suggests that their physiological cell turnover is probably regulated by the Fas-FasL apoptotic pathway, a hypothesis which seems to be corroborated by similar data recently obtained in mice, ${ }^{36}$ but that requires further investigation.

Supported by INSERM, Institut Paoli Calmettes, and grants from The Fédération Nationale des Centres de Lutte Contre le Cancer, and the Comité des Bouches du Rhône de la Ligue Cancer, and the

1 Armitage RJ. Tumor necrosis factor receptor superfamily members and their ligands. Curr Biol 1994;6:407-13.

2 Itoh N, Yonehara S, Ishii A, Yonehara M, Mizushima S, Sameshima $M$, et al. The polypeptide encoded by the cDNA for human cell surface antigen Fas can mediate apoptosis. Cell 1991;66:233-43.

3 Oehm A, Behrmann I, Falk W, Pawlita M, Maier G, Klas C, et al. Purification and molecular cloning of the APO-1 cell surface antigen, a member of the tumor necrosis factor/ nerve growth factor receptor superfamily. $₹$ Biol Chem nerve growth factor

4 Nagata S, Golstein P. The Fas death factor. Science 1995;267:1449-56.

5 Schulze-Osthoff K. The Fas/APO-1 receptor and its deadly ligand. Trends Cell Biol 1994;4:421-5.

6 Debatin KM, Goldman CK, Bamford R, Waldmann TA, Krammer PH. Monoclonal antibody-mediated apoptosis in adult $T$ cell leukaemia. Lancet 1990;335:497-500.

7 Debatin KM, Goldman CK, Waldmann TA, Krammer PH. APO-1 induced apoptosis of leukemia cells from patients with adult T-cell leukemia. Blood 1993;81:2972-7.

8 Suda T, Takahashi T, Golstein P, Nagata S. Molecular cloning and expression of the Fas ligand, a novel member of the tumor necrosis factor family. Cell 1993;75:1169-78.

9 Suda T, Nagata S. Purification and characterization of the Fas ligand that induces apoptosis. $\mathcal{F} \operatorname{Exp}$ Med 1994;179: 873-8

10 Takahashi T, Tanaka M, Inazawa J, Abe T, Suda T, Nagata $S$. Human Fas ligand: gene structure, chromosomal localization and species specificity. Int Immunol 1994;6:1567-74-

11 Tanaka M, Suda T, Takahashi T, Nagata S. Expression of the functional soluble form of human Fas ligand in the functional soluble form of human Fas ligan

12 Watanabe-Fukunaga R, Brannan CI, Copeland NG, Jenkins NA, Nagata S. Lymphoproliferation disorder in mice explained by defects in Fas antigen that mediates apoptosis. Nature 1992;356:314-17.

13 Takahashi T, Tanaka M, Brannan CI, Jenkins NA, Copeland NG, Suda T, et al. Generalized lymphoproliferative disease in mice, caused by a point mutation in the Fas ligand. Cell 1994;76:969-76.

14 Lynch DH, Watson ML, Alderson MR, Baum PR, Miller $\mathrm{RE}$, Tough $\mathrm{T}$, et al. The mouse Fas-ligand gene is mutated in gld mice and is part of a TNF family gene cluster. Immunity $1994 ; 1: 131-6$.

15 Ramsdell F, Seaman MS, Miller E, Tough TW, Alderson MR, Lynch DH. Gld/gld mice are unable to express a functional ligand for Fas. Eur f Immunol 1994;24:928-33.

16 Fisher GH, Rosenberg FJ, Straus SE, Dale JK, Middelton LA, Lin AY, et al. Dominant interfering Fas gene mutations impair apoptosis in a human autoimmune lymphoproliferative syndrome. Cell 1995;81:935-46.

17 Rieux-Laucat F, Le Deist F, Hivroz C, Roberts IAG, Debatin KM, Fischer A, et al. Mutations in Fas associated with human lymphoproliferative syndrome and autoimmunity. Science 1995;268: 1347-9.

18 Griffith TS, Brunner T, Fletcher SM, Green DR, Ferguson TA. Fas ligand-induced apoptosis as a mechanism of immune privilege. Science 1995;270:1189-92.

19 Medawar PB. Immunity to homologous grafted skin. III. The fate of skin homografts transplanted to the brain, to subcutaneous tissue and to the anterior chamber of the eye. Br f Exp Pathol 1948;29:58-69.

20 Selawry HP, Whittington KB, Bellgrau D. Abdominal intratesticular islet-xenograft survival in rats. Diabetes 1989;38: 220-3.

21 Bellgrau D, Gold D, Selawry H, Moore J, Franzusolf A, Duke RC. A role for CD95 ligand in preventing graft rejection. Nature 1995;377:630-2.

22 Sambrook J, Fristch E, Maniatis T. Molecular cloning. A laboratory manual, 2nd ed. Cold Spring Harbor, New York: Cold Spring Harbor Laboratory, 1989.

23 Xerri L, Mathoulin MP, Birg F, Bouabdallah R, Stoppa AM, $\vec{\circ}$ Hassoun J. Heterogeneity of rearranged T-cell receptor Vand V-transcripts in tumor-infiltrating lymphocytes from Hodgkin's disease and non-Hodgkin's lymphoma. $A m \mathcal{F}$ Clin Pathol 1994;101:76-80.

24 Xerri L, Carbuccia N, Parc P, Hassoun J, Birg F. Frequent expression of FAS/APO-1 in Hodgkin's disease and anaplastic large cell lymphomas. Histopathology 1995;27: O 235-4

25 Steller $\mathrm{H}$. Mechanisms and genes of cellular suicide. Science $\infty$ 1995;267:1445-9.

26 Strasser A. Death of a T cell. Nature 1995;373:385-6.

27 Alderson MR, Tough TW, Davis-Smith T, Braddy S, Falk B, Schooley KA, et al. Fas ligand mediates activation-induced cell death in human T lymphocytes. F Exp Med 1995;181: $71-7$

28 Leithäuser F, Dhein J, Mechtersheimer G, Koretz K, Brüderlein S, Henne C, et al. Constitutive and induced expression of APO-1, a new member of the nerve growth factor/tumor necrosis factor receptor superfamily, in normal and neoplastic cells. Lab Invest 1993;69:415-29.

29 Möller P, Henne C, Leithäuser F, Eichelman A, Schmidt A, Brüderlein S, et al. Coregulation of the APO-1 antigen with intercellular adhesion molecule-1 (CD54) in tonsillar B cells and coordinate expression in follicular center B cells and in follicle center and mediastinal B-cell lymphomas. Blood 1993;81:2067-75.

30 Owen-Staub LB, Meterissian S, Ford RJ Fas/APO-1 expression and function on malignant cells of hematologic and nonhematologic origin. F Immunotherapy 1993;14: $234-41$

31 Suzuki A, Enari M, Eguchi Y, Matsuzawa A, Nagata S, TsujimotoY, et al. Involvement of Fas in regression of vagina epithelia after ovariectomy and during an estrous cycle. EMBO f 1996;15:211-15.

32 Chu JL, Ramos P, Rosendorff A, Nikilic-Zugic J, Lacy E, Matsuzawa A, et al. Massive upregulation of the Fas ligand in $l p r$ and gld mice: implications for Fas regulation and the graft-versus-host disease-like wasting syndrome. $\mathcal{F}$ Exp Med 1995;181:393-8.

33 Suda T, Okazaki T, Naito Y, Yokota T, Arai N, Ozaki S, et al. Expression of the Fas ligand in cells of $\mathrm{T}$ cell lineage. $\mathcal{F}$ Immunol 1995;154:3806-13.

34 Fonseca R, Inwards DJ, Habermann TM, Colgan JP, White WL, Witzig TE, et al. Testicular lymphoma, high incidence of extra nodal relapse. Blood 1996;84(suppl 1):2122.

35 Cserr HF, Bundgaard MB. Blood-brain interfaces in vertebrates: a comparative approach. Am $\mathcal{F}$ Physiol 1984; 246:277-88.

36 French LE, Hahne M, Viard I, Radlgruber G, Zanone R, Becker $\mathrm{K}$, et al. Fas and Fas ligand in embryos and adult mice: ligand expression in several immune privileged tissues and coexpression in adult tisues characterized by apoptotic cell turnover. F Cell Biol 1996;133:335-43.

\section{, ,}

.

.

